SF

263

P8

UC-NRLF

||||||||||||||||||||||||||||||||||||||||

5 B $659 \quad 374$

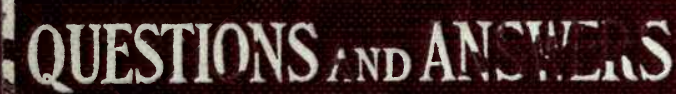

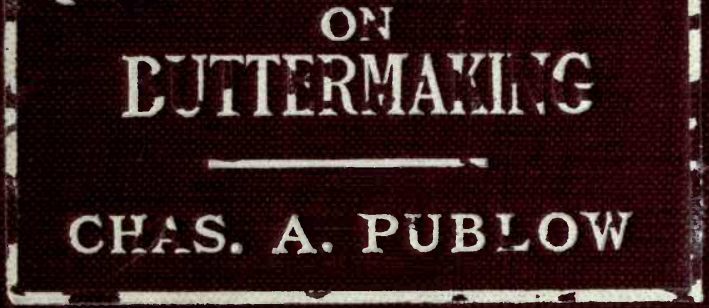


V. I. WINTERHAITKK - Gift
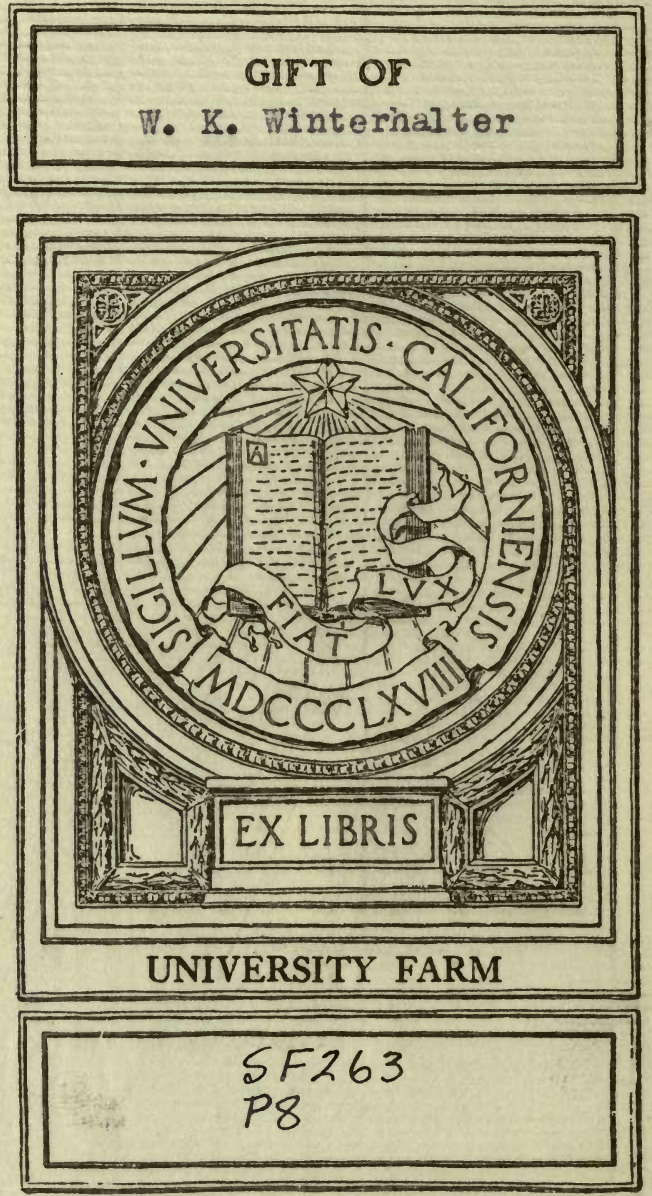



\title{
Questions and Answers 3e on Buttermaking
}

\author{
By \\ CHAS. A. PUBLOW, A. B. M. D.C. M. \\ Assistant Professor of Dairy Industry in \\ Cornell University
}

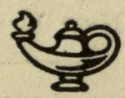

ILLUSTRATED

NEW YORK

ORANGE JUDD COMPANY

LONDON

Kegan Paul, Trench, Trubner \& Co., Limited I9I I 
Copyright, 1909

Orange Judd Company

NEW YoRK

[EXTERED AT STATIONERS' HALL, LONDON, ENGLAND]

Printed in U. S. A. 
This little book is affectionately dedicated to my father, of whom it can be said that no man was more willing to answer the questions of his students or more anxious for their success. 



\section{PREFACE}

In most of our agricultural schools and colleges many short-course students now make up a large part of the total registration, and in dairy work it is doubtful if any other class of students accomplishes so much in the same period of tuition. Perhaps the greatest difficulty or drawback to the average short-course man is his lack of preliminary school training. He can do manual work, but lack of experience in answering questions causes his failure at examination time. He knows the work, but cannot express his views in writing.

Then there are those long-experienced, practical buttermakers who wish to better their positions by trying civil service examinations. They read all current literature and know the answers in a certain way, but cannot express their thoughts as they should.

It is for this class of men, and out of sympathy for their needs, that the author has seen fit to compile this little series of question compends.

All modern literature on buttermaking has been consulted freely, with the hope of making the work more thorough and with the hope of being of the greatest service to those of our associates in dairy work.

\section{CHAS. A. PUBLOW.}

August, I909. 



\section{Questions and Answers on Buttermaking}

What is the average composition of milk?

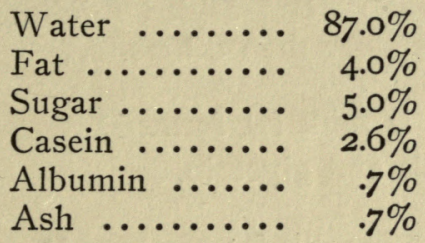

What constituents of milk are most important in buttermaking?
Milk fat.
Water.
Sugar.

Why is the milk fat most important?

Because it forms over $80 \%$ of the composition of butter.

In what form does fat in milk exist?

Milk fat exists in the form of small globules not visible to the naked eye and held in suspension in the milk serum.

What conditions affect the size of fat globules?

I. Breeds of cows.

2. Individuality of cows. 

3. Period of lactation.
4. Part of milk tested.
5. Night milking and morning milking.
6. Health of cow.

What are properties of milk fat?

Its specific gravity is about .93. Its melting point is between $90^{\circ} \mathrm{F}$. and $99^{\circ} \mathrm{F}$. When heated it becomes oily and when cooled solidifies, some parts solidifying sooner than others.

From what is milk fat formed?

Fatty acids and glycerin.

Of what fats is milk fat composed?

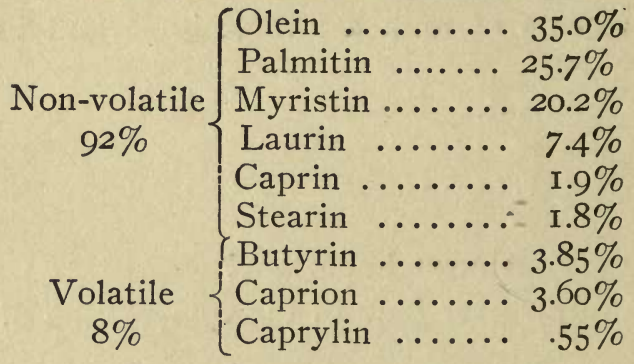

What is the theory of a film surrounding each fat globule?

Upon this subject there is great difference of opinion. Dr. Van Slyke of Geneva states that no such film exists. Dr. Storch says that a film does exist, that he has isolated and analyzed it and found it contained 94 per cent water and 6 per cent proteid. 
What is a volatile fat?

One composed of a soluble, easily vaporized, fatty acid, and glycerin.

What is a non-volatile fat?

One composed of an insoluble fatty acid and glycerin. It is not easily vaporized.

What is the melting point of the different fats?

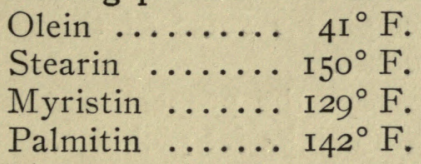

Of what value are the casein and albumin in buttermaking?

Of no particular value, as they are retained in the skim milk.

Of what value is milk sugar in buttermaking?

From milk sugar lactic acid is formed by the action of the bacteria. This knowledge is made use of in making starters, in ripening cream, in churning and in securing a desirable flavor and body in butter.

What is the color of milk due to?

I. To lactochrome.

2. To the milk fats, particularly palmitin.

How does the color of milk affect the natural coloring of butter?

During those seasons of the year in which the cow is fed grass or other succulent foods the color 
of butter is highest. During the winter when dry feed is fed the milk fat has less color.

What are the effects of pasteurizing milk at $180^{\circ}$ F. or over?

I. It destroys nearly all bacterial life.

2. It diminishes the viscosity.

3. It drives off gases.

4. It may impart a cooked taste.

5. It precipitates some of the albuminoids and ash constituents.

6. It destroys the properties of milk enzymes.

7. It splits up the fat globules.

8. It caramelizes some of the sugar.

What ferments are common in milk?

I. Organized-bacteria, yeasts.

2. Unorganized-galactase.

What is the difference between an organized and an unorganized ferment?

An organized ferment is one due to the action of bacteria and having the power of reproducing itself. An unorganized ferment or enzyme is formed by some secreting gland, has limited action and has not the power of reproducing itself.

What are bacteria?

Bacteria are the lowest forms of microscopical plants.

What bacteria are desirable in buttermaking?

Those forms that produce lactic acid from milk sugar and give a desirable flavor to butter. 
What bacteria are undesirable in buttermaking?

I. Those that produce gas and bad flavors in milk, cream and butter.

2. Those that cause ropy milk.

3. Those that cause sweet coagulation of milk.

4. Liquifying bacteria.

5. All forms that are not necessary in producing clean, wholesome butter.

Upon what conditions do bacteria depend for growth?

I. Suitable food.

2. Moisture.

3. Suitable temperature.

What are the sources of bacteria in milk, cream, and butter?

I. From stable air, especially when dust, cobwebs and manure abound.

2. From unclean hands that milk the cows.

3. From unclean utensils.

4. From contaminated water.

5. From the air of any place whose surroundings are unclean.

6. From impure starters.

7. From any unclean thing with which milk, cream, or butter comes in contact.

8. By keeping these products at too high temperature.

What are bacterial spores?

They are the generative cells by which bacteria divide and reproduce. All forms of bacteria do not form spores. 


\section{How can bacteria be killed?}

Most bacteria can be killed by heating to a temperature of $212^{\circ} \mathrm{F}$. Many forms are killed by lower temperature, but spores are not destroyed by boiling.

\section{How can spores be killed?}

By fractional sterilization, i. e., by first heating to boiling point, $212^{\circ} \mathrm{F}$, then cooling to $90^{\circ} \mathrm{F}$., - allowing remaining spores to develop at this latter temperature into bacteria and heating again to $212^{\circ} \mathrm{F}$. to kill these. This procedure may be repeated several times.

How can milk or cream be tested on the receiving platform?

I. For acidity by the use of an acidimeter.

2. For odors by sense of smell.

3. For flavors by sense of taste.

4. For insoluble dirt by eyesight and by allowing samples to stand a few minutes in small glass jars so that the dirt will settle to the bottom.

5. In cold weather flavors and odors can be detected more readily if milk and cream are warmed up by steam.

6. By the use of fermentation or Wisconsin curd test.

7. Milk can be tested for adulteration by the use of a lactometer.

8. Samples can be taken for composite bottles or for daily testing for fat.

What is the fermentation test?

Commonly called "Wisconsin curd test." Sam- 
ples of suspected milk from each patron are placed in small glass jars holding about half a pint. The milk is heated to $90^{\circ} \mathrm{F}$. and retained at this temperature to make conditions favorable for the growth of any abnormal bacteria or ferments that may be present. Cheesemakers add a small amount of rennet to the samples of milk so that a curd is formed that may be studied for defects: The samples are examined frequently during the day, and tested for odors or other defects that may have developed.

What are the uses of the fermentation test?

I. To assist in locating sources of bad flavors in milk, cream, and butter.

2. To study the nature of the milk furnished by each patron.

3. To study the action of suspected starters on samples of milk.

How should milk and cream be sampled for fat testing?

Samples of milk can be accurately measured by the use of a I7.6 c. c. pipette. They can also be weighed, using 18 grams for each test.

All samples of cream should be accurately weighed on reliable scales, using 4 grams for each sample. Accurate work cannot be done by using a pipette for measuring, as cream of different percentages of fat varies considerably in volume.

When milk and cream are paid for on the fat basis, composite samples of each patron's milk or cream are kept and tested at least twice each month 
What is meant by "overrun" in buttermaking?

The overrun is the difference between the amount of pure milk fat and the amount of butter manufactured from that given amount of fat.

How is the percentage overrun determined?

The difference between the amount of fat and the amount of butter is divided by the amount of fat and multiplied by roo.

Example: 700 pounds milk testing 6 per cent $=$ 42 pounds fat. Yield of butter made from 42 pounds fat, is 50 pounds; difference is 8 pounds (overrun) $\therefore$ percentage overrun is

$$
\frac{50-42}{42} \times 100=19 \% \text {. }
$$

Upon what does the amount of overrun depend?

I. Thoroughness of skimming.

2. Completeness of churning.

3. General losses in the creamery.

4. Composition of the butter manufactured.

5. Accuracy in sampling the cream for testing.

6. Accuracy in reading the fat in the graduated test bottles.

What is "churn-yield"?

Churn-yield is the amount of butter in relation to the amount of fat in the milk: Example:

$$
\text { ( } \left.\frac{\text { Pounds of butter }}{\text { Pounds of milk }}\right) \times 100=\text { churn-yield. }
$$

If cream is used instead of milk, the word cream is used in place of milk in this formula.

What is meant by "cream-raising coefficient"?

It is the percentage of fat removed from the milk during the process of separation. Example: 
Suppose Ioo pounds of milk containing 4 per cent fat is skimmed and it yields 85 pounds skim milk, testing .2 per cent fat and 15 pounds cream.

Total fat in whole milk $=100 \times .04=4$ pounds.

Total fat in skim milk $=85 \times .002=.17$ pound.

Total fat in cream $=4-.17=3.83$ pounds.

$$
\frac{3.83 \times 100}{4}=95.75 \text {. }
$$

$\therefore$ the cream-raising coefficient is 95.75 per cent.

Should a patron who furnishes cream be paid more per pound of fat than the patron who delivers whole milk?

Theoretically, he should, because there is no separator loss to the creamery when cream is furnished. However, it is doubtful if such a plan can be fairly conducted in many places, because the quality of the cream or fat determines largely its market value. Usually butter made by whole milk creameries is superior to that made in cream-gathering creameries, so, taken all in all, it is doubtful if any difference should be made in the price of fat.

Why is milk heated or tempered before separating?

I. Because all separators skim closer and do not clog so easily.

2. Viscosity of milk is decreased.

3. Fluidity of milk is increased.

4. Increases the ease of fat separation.

What is the best temperature for separating milk by centrifugal force?

About $90^{\circ} \mathrm{F}$. 
What are the advantages of high heating before separation?

I. Undesirable taints are largely eliminated.

2. Bacteria are killed in the skim milk and cream.

3. Less heating and cooling apparatus is necessary.

4. Closer skimming.

5. Less labor and smaller cost of heating.

How should milk be heated before separation?

I. By some special heater that heats the milk indirectly with steam or hot water. This is the best method.

2. By the use of a double-jacketed vat in which hot water can be used. This is a common method, but it has two serious objections:

(I) Milk is kept warm too long before separation, favoring the rapid growth of bacteria.

(2) If for any reason the separator or machinery should break down, the warm milk will soon sour, especially during warm weather.

Why is it not advisable to heat milk by direct steam?

I. Steam from impure water may introduce bad flavors into the milk.

2. It is too sudden.

3. The butter may have a burnt or oily flavor.

Why is fat separated from milk for churning?

I. To reduce the bulk.

2. To save fat. Fat is more easily removed by separation than $b_{\bar{y}}$ churning. 
3. For commercial purposes.

4 To facilitate cream ripening.

5. To secure sweet skim milk.

What are the different methods of cream separation?
I. Centrifugal $\left\{\begin{array}{l}\text { hand separators. } \\ \text { power separators. }\end{array}\right.$
2. Gravity $\left\{\begin{array}{l}\text { shallow-pan method. } \\ \text { deep-setting method. } \\ \text { water-dilution method. }\end{array}\right.$

What are the advantages of centrifugal separation over gravity separation?

I. More rapid.

2. More thorough.

3. Better cream, that can be of any desired percentage of fat.

4. Fresher skim milk.

5. Fermentations can more easily be controlled.

6. Centrifugal force removes insoluble dirt from milk.

7. Less danger of milk and cream absorbing bad odors.

8. Insures a more even quality of butter.

9. Less labor involved.

What are the advantages of the shallow-pan system?

I. Cheapness.

2. Simplicity.

What are its disadvantages?

I. Heavy loss of fat. This method saves only about 80 per cent of the fat. 
2. Requires much space.

3. Requires much labor.

4. Milk may become seriously contaminated by long exposure in unclean places.

5. Cannot fully control the ripening of milk.

6. The skim milk is not in the best condition for feeding to calves.

What are the advantages of the deep-setting system?

I. Furnishes good cream.

2. Easy to operate.

3. Not expensive.

4. Very good system if one has ice or cold water.

What are the disadvantages?

I. Considerable loss of fat. Seldom can more than 93 per cent of the fat be secured by this method.

2. Skim milk is not fresh, although sweet.

What are the disadvantages of the dilution method?

I. Greater bulk.

2. Skim milk less valuable.

3. Danger of undesirable bacteria in impure water.

4. Cream is not normal in solids-not-fat composition.

5. Loss of fat is as great as in deep-setting system.

What four principles have been used by separator manufacturers?

I. Revolving bucket centrifuge. 


\section{W. R. WINTEREALTWK \\ ON BUTTERMAKING}

2. Intermittent hollow bowl.

3. Continuous hollow bowl.

4. Continuous separator, with contrivances within the bowl.

What is the principal part in separator construction?

A hollow bowl with or without inner devices and rotating at high speed in a vertical position.

Into what three layers does milk divide in a revolving separator bowl?

I. Separator slime on the outside.

2. Skim milk next the slime.

3. Cream nearest the center of the bowl. The richest cream is in the very center of the bowl.

What is the composition of separator slime?

It is made up of casein, insoluble dirt, bacteria, fat, water, ash, albumin, and foreign bodies.

Fleischmann gives the following:

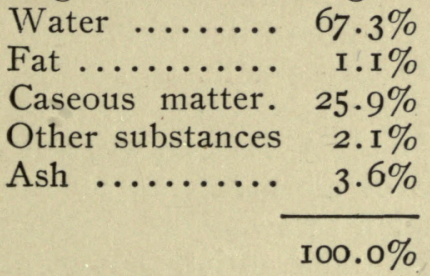

What is the cream screw?

It is the outlet by which the cream leaves the separator bowl. 
How does altering the position of the cream screw affect the composition of the cream?

Turning it in toward the center of the bowl increases the richness of the cream.

Turning it away from the center causes the cream to be thinner.

What is the relation between the skim-milk outlet and the running of the separator?

The nearer the skim-milk outlet can be brought to the center of the bowl, the easier will the machine run. Usually the skim-milk outlet is brought in toward the center of the bowl at one end through tubes extending from the circumference of the bowl.

What conditions affect the amount and richness of cream obtained?

I. Richness of the milk.

2. Speed of the bowl.

3. Rate of inflow of milk.

4. Position of the cream screw and skim-milk outlet.

5. Temperature of the milk.

6. Acidity of the milk.

What are the most common ways of regulating the richness of cream?

I. By cream screw.

2. By skim-milk outlet.

3. By inflow of milk.

What are the causes of cream being too thick?

I. Cream screw too near center of the bowl. 
2. Cream outlet may be clogged.

3. Milk inflow may be insufficient.

4. Speed of machine may be too high.

5. Milk may be very rich.

6. Milk may be too cold.

What are the causes of cream being too thin?

I. Cream screw too far from center of bowl.

2. Skim-milk outlet may be clogged.

3. Milk inflow may be too fast.

4. Speed of machine may be too low.

5. Milk may be very poor in fat.

What is the running speed of the common power separators?

De Laval, 5,600 revolutions per minute.

United States, 8,500-9,000 revolutions per minute. Simplex, 6,500 revolutions per minute. Tubular, I4,000-I 5,000 revolutions per minute. Sharples, I4,000-I5,000 revolutions per minute.

How is the speed of separators determined?

All modern machines have a speed indicator consisting of a small wheel, which can be pushed against the wormed part of the separator's revolving spindle. Most indicators make only one revolution while the bowl turns roo times. In testing the speed it is necessary to have a watch or clock with second hands so that the number of revolutions of the small wheel in a given number of seconds can be determined.

Example: The speed indicator is pushed against the revolving spindle for Io seconds. During that time the indicator turns 12 times. Every turn of 
the indicator means roo turns of the separator bowl and spindle. Therefore, in ro seconds the bowl revolves $100 \times 12$, or 1,200 times. Ten seconds is one-sixth of a minute. Therefore, in a minute the bowl revolves $1,200 \times 6$ times, 7,200 times.

The speed of all modern separators can be easily figured in this way. Each turn of the indicator on the

De Laval means Ioo turns of the bowl.

Unịted States means Ioo turns of the bowl. Simplex means 50 turns of the bowl. Tubular means 250 turns of the bowl. Sharples means 250 turns of the bowl.

Upon what does the centrifugal force of a revolving separator bowl depend?

I. It varies in direct proportion to the diameter of the bowl, i. e., the greater the diameter the less speed is required in order to get a certain force.

2. It varies in quadratic proportion to the speed of the machine, i. e., if the speed is doubled the centrifugal force is increased four times.

What are the disadvantages of a large bowl?

I. It more easily gets out of balance.

2. It is harder to keep on bearings.

3. It is heavy and hard to handle.

How should a separator bowl be flushed after running?

I. With skim milk.

2. With warm water at about the same temperature as the milk. 
How thick should farm separated cream be?

The thicker the better. The farmer then has more skim milk for feeding purposes and has less cream to handle. Rich cream will take longer in souring. Cream testing 40 per cent fat makes a desirable cream for farm-separator and butter work.

What are the advantages of owning a farm separator and making butter on the farm, rather than send the milk to a creamery?

I. The milk can be skimmed as soon as milked, with small loss of fat, giving perfectly fresh skim milk for feeding purposes.

2. No expense for delivering milk to the creamery and drawing skim milk home.

3. No danger of transmitting disease from other herds through skim milk.

4. The cream can be easily controlled and ripened.

5. A better quality of butter can be made, all other things being equal.

6. The farmer is more independent.

What are the disadvantages of this method?

I. Cost of separator and buttermaking equipment.

2. Considerable labor involved.

3. If the cream is not churned every day or two the flavor of the butter suffers.

4. Unless the butter is well made and a special trade is established, it will not sell for as much money as does creamery butter. 
5. A suitable sanitary place must be provided for ripening cream and for cooling butter.

6. Scarcity of farm help.

What precautions would you observe in operating a separator?

I. Follow the directions of the manufacturer.

2. Keep the machine level and on a solid foundation.

3. Keep all parts of the machine absolutely clean.

4. Keep all moving parts well oiled with the recommended oil.

5. Start the machine slowly.

6. Fill the bowl with warm water before starting.

7. Keep the speed even and the milk feed supply steady.

8. When through separating flush the bowl with skim milk and warm water.

9. Allow the revolving bowl-to stop slowly.

Io. Keep the machine and its parts in good repair.

II. Test the skim milk frequently.

\section{What is pasteurization?}

Pasteurization consists in heating milk to at least $140^{\circ} \mathrm{F}$. for at least ten minutes, for the purpose of destroying bacterial life. The heating is followed by rapid cooling to check spore formation. The word is derived from Pasteur, a French scientist.

What methods of pasteurization are used?

I. Continuous; that is, heating continuously for considerable time. 
2. Intermittent; that is, heating and cooling milk alternately several times with the idea of allowing spore development between heatings. After the third heating to a high temperature, practically all bacteria and spores are destroyed.

\section{What is sterilization?}

This term is often wrongly used in place of pasteurization. To sterilize milk it must be heated to very high temperature under pressure. Milk is not sterile until every bacterium and spore is destroyed.

What are the advantages of pasteurization in buttermaking?

I. Most bacteria can be destroyed in milk and cream.

2. Commercial starters can be prepared and carried on for indefinite periods.

3. Pasteurization of skim milk prevents transmission of tuberculosis and other such diseases through its medium.

4. Many volatile and food flavors can be removed from milk and cream.

5. Cream ripening can be more successfully controlled.

6. A more uniform quality of butter can be made.

7. Butter has better keeping quality.

8. Enables separators to skim closer.

What are the disadvantages of pasteurization in buttermaking?

I. Cost of machinery, fuel and labor. 
2. Requires ice or cold water for cooling purposes.

3. Butter may have an oily texture if high temperature is improperly used.

What are the names of some of the best pasteurizing machines?

I. Simplex.

2. Jensen.

3. Miller.

4. Reid.

5. Farrington.

What are the important features in a pasteurizing machine?
I. Durability.
2. Capacity.
3. Cost.
4. Efficiency.

Upon what does the efficiency of the machine depend?

I. Kind of material from which the heating surface is manufactured.

2. Degree of adhesiveness of milk or cream on the heating surface.

3. Thickness of layer of condensed steam on steam side of heating surface.

4. Difference in temperature on each side of heating surface.

5. Proper utilization of steam turned into the Dasteurizer. 
What is the average cost of pasteurizing in buttermaking?

This varies in many localities and under many conditions, but the average cost can be fairly estimated as being about $1 / 10$ of a cent on every pound of butter manufactured.

What is meant by cream ripening?

Ripening is a process by which cream is prepared for churning. It consists in controlling the souring by controlling temperatures and the growth of bacteria both in the cream and in starters used.

Why do we ripen cream?

I. To control the growth of lactic acid bacteria.

2. To produce a desired amount of lactic acid in the cream.

3. To lessen the viscosity of cream.

4. To increase the churnability of cream.

5. To prevent losses in churning.

6. To produce flavor and aroma in the butter.

7. To increase the keeping quality of the butter.

What changes take place in cream during the ripening process?

I. Great increase in the number of bacteria.

2. Increased amount of lactic acid is formed.

3. Reduction in the amount of milk sugar due to the formation of acid.

4. Formation of various compounds in small quantities due chiefly to the action of bacteria and bacterial products.

5. Thickening due to coagulation of casein.

6. The cream surface becomes glossy. 
7. Viscosity is lessened.

8. Cream develops a characteristic aroma and taste.

How is cream ripened?

I. Naturally, i. e., by allowing the cream to stand at a favorable temperature until sour enough for churning.

2. Artificially, i. e., by the use of starters. These may be buttermilk, sour skim milk or commercial starters. Usually the cream is first pasteurized.

What are the disadvantages of natural ripening?

I. The growth of undesirable bacteria cannot be controlled.

2. Great difficulty in making a uniform quality. of butter.

3. Takes too much time if low temperature is used.

4. Quality of cream and butter is usually defective in flavor.

What are the advantages of ripening cream with a commercial starter?

I. The growth of lactic acid bacteria and the formation of lactic acid can be controlled.

2. The growth of undesirable bacteria can be almost entirely prevented.

3. Less difficulty in making a uniform quality of butter.

4. Flavor of butter can be greatly improved.

5. Butter has better keeping quality.

6. Advantages of pasteurization can be gained.

7. Time is saved. 
How is a commercial starter prepared for use?

A small bottle containing a culture of lactic acid producing bacteria is procured from some dairy bacteriology laboratory, or from some reliable dairy supply house. Directions are usually sent out with these, but the following method is the one usually followed:

Place I quart of clean, sweet milk in a sterile glass jar. Heat the milk gradually in water until a temperature of $200^{\circ} \mathrm{F}$. is reached. Hold at this temperature for at least one hour. Then allow the milk to cool to $90^{\circ} \mathrm{F}$., being careful not to place the glass suddenly in cold water.

As soon as $90^{\circ} \mathrm{F}$. is reached the content of the small bottle is carefully added to the milk and mixed through it. The mixture is now allowed to cool gradually to $70^{\circ} \mathrm{F}$. and then retained at this temperature for 24 hours, when it should be sour. This is called a " mother-starter," or " starter-line," and is not to be used in ripening the cream, but in preparing starter for the following day.

To do this, take 100 pounds of clean, sweet skim milk in a previously sterilized can and heat to at least $200^{\circ} \mathrm{F}$. for at least one hour. Then cool rapidly to $70^{\circ} \mathrm{F}$. and add the contents of the quart jar prepared the day previous, mixing it thoroughly through the milk with a sterilized dipper. Hold at $70^{\circ} \mathrm{F}$. for 18 to 24 hours, when it should be sour, slightly coagulated and clean in flavor. A small amount of this is saved out to inoculate the starter for the following day, and the process can be repeated and carried on in the same manner from day to day. 
What precautions should be observed in preparing and using a commercial starter?

I. Absolute cleanliness in all things that come in contact with the milk.

2. Use sanitary utensils.

3. Use correct thermometers.

4. Be exact on temperature.

5. Use the best milk obtainable for making the starters.

6. Add starter to cream as early as possible.

7. Do not use excessive amount of starter.

How much commercial starter should be used in cream ripening?

This will vary according to:

I. Temperature of cream.

2. Richness of cream.

3. Acidity of the starter.

4. Time required for ripening.

5. Purity of cream.

6. Kind of butter desired.

Good results can sometimes be obtained by using as much as 50 per cent starter, but the usual amount is from Io per cent to 20 per cent of the cream to be ripened. One point that should be remembered is that the greater the amount of buttermilk, the greater is the loss of fat in churning.

How much acidity should be developed in a commercial starter?

About .7 per cent.

Is a commercial starter a pure culture?

It may be or it may not. Usually it is not. 
What are the qualities of an ideal commercial starter?

I. It should have a clean, sour taste and a mild, characteristic aroma.

2. It should be nicely curdled, but not hard or lumpy.

3. It should have about .7 per cent acidity.

4. A brownish color indicates thorough pasteurization.

5. It should be glossy and have a liver-like consistency.

\section{What are the common defects in starters?}

I. They may contain large numbers of undesirable bacteria.

2. They may be "gassy."

3. They may have a bitter taste due to overdevelopment of acid or from being kept at too high temperature.

4. They may curdle while heating, due to abnormal or over-ripe milk.

5. They may be "slimy" or "ropy," due to imperfect pasteurization.

6. They may become "wheyed-off," caused by over-development of acid or too high temperature.

What are the effects of a bad starter upon the quality of the butter?

I. The flavor of the starter will be imparted to the butter and buttermilk.

2. Mechanical losses are greater.

3. Keeping quality of the butter is greatly impaired. 
What are some of the reliable commercial cultures on the market?

Hansen's, Little Falls, N. Y.

O. Douglas's, Boston, Mass.

S. C. Keith's, Charleston, Mass.

Ericsson's, St. Paul, Minn.

Parke, Davis \& Co.'s, Detroit, Mich.

\section{At what temperature should cream be ripened?}

Most buttermakers are now agreed that a temperature between $60^{\circ} \mathrm{F}$. and $70^{\circ} \mathrm{F}$. gives the best results. The cream should be cooled to churning temperature a few hours before churning.

Why should cream be stirred during the ripening process?

I. To insure uniform development of lactic acid.

2. To keep the fat and acid thoroughly mixed.

3. To keep the temperature even.

4. To prevent the cream surface drying.

5. To prevent loss of fat.

6. To prevent white specks of casein in the butter.

What difference should be made in ripening when cream is churned every other day?

The method most successfully used is as follows: Begin ripening at once with the first lot of cream skimmed and let the lactic acid bacteria get a start. In a few hours cool to at least $50^{\circ} \mathrm{F}$. and hold till the following day, when the freshly skimmed cream can be thoroughly mixed with it. The cream from the first day thus acts as a starter for the cream of the second day. The lactic acid inhibits the 
growth of undesirable bacteria so that better results are accomplished. A great mistake is too often made by holding cream too long. The longer it is held after being ready for churning, the more the flavor and quality of the butter suffers.

What conditions determine whether cream of different qualities should be mixed?

I. Quality of the cream.

2. The kind of market for the butter.

3. The amount of poor cream compared with the quantity of good cream.

4. General creamery conditions, such as facilities for pasteurizing, making starters, and for cream ripening.

How much acid should be developed in cream for churning?

This varies with the amount of fat in the cream and the kind of butter desired. Usually $20 \%$ cream should have about $.7 \%$ $30 \%$ cream should have about $.6 \%$ $40 \%$ cream should have about $.5 \%$ $50 \%$ cream should have about $.4 \%$

The richer the cream, the less sugar it contains for acid formation.

How is the acid in milk, cream, starters, or buttermilk measured?

By an acidimeter.

Describe an acidimeter and the method of testing.

There are several tests for measuring acid and sold on the market under different names, such as 
Publow's, Mann's, Farrington's, and Marshall's, but the principle is the same in all of them. An alkaline solution of known strength and an indicator called phenol-phthalein are the reagents used. The purpose of the indicator is to indicate the reaction of the milk or cream; i. e., it shows whether the milk or cream is acid, alkaline, or neutral. The indicator has no color effect in an acid solution, but it turns an alkaline substance red. When the neutral point is reached, the faintly pink color is barely distinguishable.

To make the test:

A known quantity of the milk or cream to be tested is placed in a white cup. To it a few drops of indicator are added. An alkaline solution of known strength is then allowed to run in drop by drop from a graduated burette until the milk or cream assumes a faintly pink color, which signifies that all the acid in the milk or cream has been neutralized by the alkali used. The amount of alkali used can be read on the burette, and as its strength is known it is an easy matter to figure the amount of acid in the milk or cream. One c. c. of $1 / 10$ normal alkali neutralizes .009 grams lactic acid.

In the test used at Cornell university the alkali used is a $1 / 10$ normal solution of caustic soda. This makes a very convenient strength, because when 9 grams of milk or cream are taken,..I c. c. of it neutralizes or represents oI per cent of lactic acid. Thus, if in testing the cream 4 c. c. of the alkali was used, the cream contained .40 per cent of acid.

In Farrington's test the alkali is made $1 / 50$ normal by adding 5 tablets in 97 c. c. water. Then, when 
I7.6 c. c. of cream is taken, I c. c. of the alkali represents .or per cent acid.

In Mann's test a $1 / 10$ normal alkali is used and 50 c. c. of cream are tested. The number c. c. of alkali necessary to neutralize the acid measures in degrees the amount of acid.

I c. c. of $\frac{\mathbb{N}}{10}$ alkali=I degree Mann's test.

To get the per cent acid multiply the number c. c. alkali used by .009 , divide by 50 and multiply by 100 .

\section{What is the object in churning?}

It is the agitation or concussion of the cream to a degree sufficient to separate the fat-globules from the milk and cause them to unite into masses of butter large enough to be easily separated from the buttermilk.

What conditions affect the churnability of cream?

I. Temperature of the cream.

2. Acidity of the cream.

3. Richness of the cream.

4. Size of the fat-globules.

5. Nature of the agitation.

What is the effect of temperature on the churnability of cream?

I. The higher the temperature, the sooner the churning process will be completed.

2. High temperature causes the butter to come in soft lumps instead of in a firm granular form.

3. High temperature causes too much buttermilk to remain in the butter. 
4. The excessive buttermilk usually causes mottles.

5. Too low temperature causes difficult churning.

6. Low temperature increases the viscosity of cream.

7. Low temperature causes the granules to become so hard that the butter takes up salt slowly, and the butter is difficult to work.

8. If the granules are too firm and cold, too much water is lost from the butter in working, decreasing the overrun.

What conditions influence the hardness of the fatglobules in churning?

I. The breed of the cow.

2. Individuality of the cow.

3. The food of the cow.

4. Season of the year.

5. Stage of lactation period.

6. Abnormal conditions.

Under normal conditions at what temperature should cream be churned?

Between $50^{\circ}$ and $60^{\circ} \mathrm{F}$. A very popular temperature is $56^{\circ} \mathrm{F}$. The churning should be completed in at least one hour.

\section{What is a combined churn?}

One in which cream can be churned and containing some device for working the butter.

What are the advantages of a combined churn?

I. Butter can be churned, washed, salted, and worked without being removed from the churn. 
2. Saves time and labor.

3. Temperature of butter can be easily controlled.

4. Flies are kept away from the butter during working.

What are the names of some of the best combined churns on the market?

I. Victor.

2. Wizard.

3. Simplex.

4. Disbrow.

5. Dairy Queen.

6. Squeezer.

How should a new churn be prepared for use?

It should first be washed out with plain, warm water. Then rinsed with hot salt water. Then salt water should be left in the churn for at least 24 hours, so that the pores of the wood become closed and filled with salt. If desirable, the churn may be steamed on the inside before soaking in salt water. After this treatment the churn is rinsed with cold water and is then ready for use.

How should a churn be treated to keep it in a clean, sweet condition?

After use the churn should be rinsed with warm water, then rinsed again with hot water, and finally rinsed again in hot water in which some lime has been dissolved. Sometimes steam and salt solutions are used for the final rinsing, but they are not so satisfactory as hot lime water. Nothing will do more to preserve the sweet, fresh condition of the churn than this simple method. 
How can the growth of mold be prevented in a churn not in constant use?

Before putting the churn aside give it a thorough soaking in a hot solution of bichlorid of mercury, strength one in a thousand. This is made by dissolving $7 \frac{1}{2}$ grains of mercuric chlorid in I pint hot water. The churn should then be kept in a dry place. Before using the churn again, it should be thoroughly washed with hot salt water in order to remove all traces of mercury, which is a poison.

When can the greatest amount of agitation be obtained in a churn?

When it is about one-third full.

What is the effect of revolving a churn too fast? The agitation is lessened and may even stop.

What is the effect of revolving a churn too slowly?

The cream is not agitated sufficiently, and churning is greatly delayed.

Why should cream be strained before churning?

I. It separates all lumps.

2. Separates other insoluble bodies that may be present.

3. Assists in preventing mottled color.

Why is artificial butter color used?

To maintain a uniform color in the butter during all seasons of the year.

What is used to color butter?

Most color is prepared from the seed fruit of the 
annatto tree. Carrot juice and the extract from several plants have been used. Several artificial colors have been marketed, but the United States pure food laws prevent their use in butter.

\section{How much coloring is used in buttermaking?}

This depends upon the market requirements, upon the season of the year, upon the strength of the color, and upon the natural color and richness of the milk fat.

The amount varies between none and 2 ounces for every roo pounds of milk fat. Most eastern markets want a pale, straw color, while the southern markets demand a much redder color.

How is color added to butter?

The color is diluted in a small amount of cold water and added to the cream before churning. If for any reason it is forgotten at this time, it can be mixed with the salt and applied, but this is not a desirable method, as the butter is usually overworked in so doing.

What objection is there to mixing sour cream and sweet cream before churning?

I. The creams do not mix well.

2. The sour cream churns more rapidly than the sweet.

3. There is usually heavy loss of fat in the buttermilk.

4. The color may be mottled from casein coagulated by acid in the sour cream. 
How would you tell when cream is churned enough?

I. By the size of the butter granules. These should be about the size of corn kernels.

2. By the appearance of the buttermilk. This should be bluish in color and clear.

3. By the height at which the butter floats on the buttermilk. Should be well up.

What is the effect of churning the cream too long?

I. The granules of butter become too large and retain too much buttermilk, which is difficult to remove.

2. There is danger of incorporating too much moisture in the butter.

3. If the cream is of poor flavor, the excessive moisture and buttermilk injures the keeping quality of the butter.

4. The texture of the butter is injured.

What is the effect of too much buttermilk in butter?

I. The sugar in the buttermilk sours and injures the flavor.

2. The casein usually causes mottled color.

3. Keeping quality is injured.

4. The texture of the butter is injured.

What is the effect of stopping the churning process too soon?

I. The butter granules are too small and manv of them are lost in the buttermilk.

2. There is difficulty in holding moisture in the butter and it may cause leaking butter. 
What are the causes of difficult churning?

I. Small fat-globules. Usually found in milk from stripper cows or cows far advanced in the lactation period.

2. Cream may become frothy, due to some abnormal condition of the milk from a diseased cow, or from foreign substances of an alkaline nature added to milk or cream.

3. The milk or cream may be "yeasty."

4. The churn may be too full.

5. Cream may be too thick.

6. Cream may be too thin.

7. Cream may be too cold.

8. Cream may be too sweet.

What are the remedies for difficult churning?

I. See that the cream is not too thick nor too thin, of proper acidity, and of correct temperature.

2. Do not overfill the churn.

3. If due to the milk from a certain cow or herd, keep this by itself.

4. Succulent food, such as ensilage, usually remedies the trouble in milk from errors in dry feeding.

5. Ripen the cream to a higher acidity.

6. Use a good commercial starter.

What is the cause of frothy cream?

I. Abnormal condition of cream due to diseased condition of cows.

2. Certain bacteria and bacterial products.

3. "Yeasts." Quite common in recent years.

4. Alkaline preservatives added to milk or cream. 
5. Cream too sweet.

6. Churn too full.

How would you treat cream that froths in a churn?

I. Correct errors in temperature, acidity, fullness of churn, etc.

2. For immediate treatment, add some warm water around the outside of the churn.

3. If a combined churn is used, start the rollers.

4. Some warm water may be added directly to the cream.

5. By allowing the churn to stand quiet a while the froth may settle and churning can then be completed.

6. Pasteurize the cream.

7. Use a good commercial starter and ripen the cream a little more than usual.

8. When the trouble continues after the above treatments, thorough investigation should be made into the milk supply and the source of all water supply.

\section{Why is butter washed?}

To remove as much of the buttermilk as possible.

When should butter be washed?

Just as soon as all the free buttermilk can be removed.

What temperature should the wash water be?

It should be as nearly like that of the cream when churned as is consistent with other conditions. 
What is the effect of using too cold water?

I. It chills the butter.

2. It hinders the escape of buttermilk.

3. It may cause a tallowy appearance in the butter.

4. It lessens the moisture content of the butter.

\section{What is the effect of using too warm water?}

I. It tends to increase the moisture content of butter.

2. It injures the texture of the butter, causing it to become greasy and soft.

What is the effect of excessive washing of butter?

I. It removes some of the flavor from butter.

2. If the water is warm it increases the moisture content of the butter.

3. It injures the texture of the butter.

\section{How should butter be washed?}

Water at about the same temperature as the buttermilk should be put on in sufficient quantity to remove all the buttermilk. Sometimes one washing is enough, but usually two or three waters must be used. When the last water is used it should run away perfectly clear. If the granules of butter are very soft, the last water can be colder than the first, but, in order to retain a high moisture content in the butter, the water must not be too cold.

Sometimes when the flavor of butter is not good, excessive washing is resorted to, but this does not usually have a very beneficial effect, especially if the bad flavor is of bacterial origin. Some volatile 
food flavors, however, are materially decreased by washing in good water.

What conditions affect the moisture content of butter?

I. Richness of the cream.

2. Temperature of the cream and wash water.

3. Size of butter granules.

4. Time allowed butter in buttermilk and wash water.

5. Amount of working the butter receives.

6. Minor mechanical conditions.

What is the maximum amount of moisture in butter - allowed by the laws of United States?

The moisture content of butter must be under 16 per cent.

What methods are used for purifying water at creameries?

I. Filtration through a sand filter

2. Pasteurization.

Pure spring water or good well water does not need purifying.

What is the effect of the presence of buttermilk in butter?

I. The keeping quality of the butter is injured.

2. The presence of casein usually causes a mottled color.

3. The texture of the butter is injured, the milky brine being quite objectionable to many consumers. 
What are the reasons for salting butter?

I. To give it flavor.

2. To assist in expelling buttermilk.

3. To increase the keeping quality.

Upon what conditions does the amount of salt used depend?

I. Upon the market requirements.

2. The moisture content of the butter.

3. The strength of the salt.

4. The amount of working the butter receives.

5. Size of the butter granules at time of salting.

6. Upon the flavor of the butter.

What is the composition of pure dairy salt?

Sodium chlorid...... 99.18\%

Magnesium chlorid.. $.05 \%$

Gypsum .......... $\quad .54 \%$

Calcium chlorid..... . . $19 \%$

Insoluble matter .... $.03 \%$

Moisture ........... .01\%

$100.00 \%$

Upon what does the amount of salt dissolved in butter depend?

I. Upon the amount of moisture in the butter.

2. Upon the purity of the salt.

How does salt increase the keeping quality of butter?

I. By its antiseptic power.

2. By assisting in the removal of buttermilk. 


\section{What is brine-salting?}

The butter is salted by being washed or soaked in a salted water.

What are the advantages of brine-salting?

I. Overrun can be increased.

2. There is very little danger of mottled color.

3. Butter requires less working.

What are the disadvantages of brine-salting?

I. It is too expensive.

2. Requires considerable water.

3. Increased labor.

4. Difficulty in getting sufficient salt into the butter.

5. May cause excessive amount of moisture in butter.

6. Color may be streaked if insufficient working is given.

\section{What is the effect of salt in buttermaking?}

I. Helps to expel buttermilk.

2. Gives flavor to butter.

3. Adds weight to butter.

4. Causes the color of butter to become more pronounced.

5. It acts as a preservative and increases the keeping quality of butter.

6. Affects the body and texture of butter.

What is the average salt content of butter?

About 2 per cent. 
How much salt can be incorporated in butter?

As much as 7 per cent or 8 per cent, but then most of it is in an undissolved state. It is difficult to incorporate more than 3 per cent of dissolved salt.

\section{How is butter tested for its salt content?}

I. Weigh into a glass beaker Io grams of butter. Add about 20 c. c. water and warm the mixture to melt the butter. Then transfer the butter and water to a separatory funnel. Insert the stopper and shake for a few minutes. Then allow the mixture to stand a few minutes until any remaining fat has collected on the surface. Then draw the water into a flask, being sure that no fat passes through. Again, add hot water to the beaker and repeat the washing in the funnels several times, using I $_{5}$ c. c. water each time.

Determine the sodium chlorid or salt in a measured part (IO c. c.) of the liquid by titrating with standard silver nitrate solution, using potassium chromate as an indicator.

One c. c. $\frac{\mathbb{N}}{10}$ silver nitrate solution equals .005837 grams of salt.

To determine the total amount of salt divide the total number c. c. of water used by ro and multiply by .005837 . This will give the total number grams of salt in ro grams of butter.

Then, knowing the amount present in Io grams, it is an easy matter to determine the amount in 100 grams by multiplying by Io. This gives the percentage of salt in the butter tested.

2. Gray's salt test. A representative Io-gram sample of butter is placed in a small glass dish. 
The dish is then half filled with boiling water and the mixture of fat and water poured into a $500 \mathrm{c}$. c. glass flask. The dish is rinsed several times with boiling water and each time the rinsing is poured into the flask. The flask is then filled to the 500 c. c. mark with boiling water and thoroughly shaken. Then allow the contents of the flask to cool, and after the fat has collected on top and solidified, measure with a pipette $50 \mathrm{c}$. c. of the clear solution beneath the fat and place it in a clean glass dish. Fifty c. c. of a potassium chromate indicator is then added and the solution titrated with a standard silver nitrate solution. The strength of this silver solution is such that I c. c. of it represents $1 / 100$ of I per cent of salt.

3. The Fitch salt test. A representative 3.5 gram sample of butter is placed in a 300 c. c. glass flask and $\mathrm{I} 8 \mathrm{o} \mathrm{c}$. c. boiling water added. The flask is then corked and thoroughly shaken, care being taken to remove the cork often to relieve pressure. The mixture is then allowed to cool, and after the fat has collected on top and solidified, I7.6 c. c. of the clear solution beneath the fat is placed in a white cup. Then I7.6 c. c. of potassium chromate indicator is added, and the solution titrated with a standard silver nitrate solution measured from a graduated cylinder till the solution becomes a permanent reddish color. The number c. c. silver nitrate used divided by ro equals per cent salt.

\section{How should salt be added to butter?}

As soon as the butter has been properly washed the salt should be applied by passing it through a fine-meshed sifter in order to prevent lumps of salt 
entering the butter. The salt should be given plenty of time to dissolve before the butter receives its final working.

\section{What is "gritty" butter?}

Butter in which part of the salt remains in an undissolved state.

What are the causes of "gritty" butter?

I. Excessive salting.

2. Impure salt.

3. Small water content of butter.

4. Insufficient working.

5. Uneven distribution of salt.

6. Failure to allow butter to stand after salting before final working.

What is mottled butter?

Butter which is uneven in color, having lighter and darker spots.

What are the causes of mottled butter?

I. Specks of casein from buttermilk.

2. Improper incorporation of salt.

3. Yeasts.

4. Failure to strain the cream or starter.

5. Poor coloring.

How can mottled butter be prevented?

I. By thoroughly removing the buttermilk by washing.

2. By allowing the salt plenty of time to dissolve before completing the butter working.

3. By using pure salt. 
4. By giving the butter sufficient working.

5. Always strain cream and starter.

6. By using reliable coloring.

How can mottles be removed from butter?

Most mottles can be removed by excessive working of the butter.

Why is butter worked?

I. To assist in distributing salt through the butter.

2. To assist in expelling buttermilk and water.

3. To bring the granules of butter into a more compact form.

How much should butter be worked?

This depends on the condition of the butter and the style of butter worker. Butter should be worked till the salt is dissolved, till the color is uniform and the moisture content is satisfactory. About 12 to 20 revolutions of most combined churns is sufficient.

What is the average composition of butter?

$$
\begin{array}{lr}
\text { Fat } \ldots \ldots \ldots \ldots & 84.00 \% \\
\text { Water } \ldots \ldots \ldots & \text { I } 2.73 \% \\
\text { Curd ......... } & \text { I.3\% } \\
\text { Salt and ash... } & \text { I.97\% } \\
\cline { 2 - 2 } &
\end{array}
$$

When is cheesemaking more profitable than buttermaking?

When butter sells for less than two and onethird times as much as cheese. 
What amount of fat should be present in butter?

Not less than 80 per cent.

\section{How should butter be packed for shipment?}

This depends on the requirements of the different markets. Regulation wooden tubs containing Io, 20,30 , or 60 pounds are used most extensively in the United States. In Canada most of the butter made for export is packed in square boxes, holding about 56 pounds. Dairy butter is usually packed in earthen jars, and nothing gives better satisfaction.

In many creameries the butter is wrapped in pound prints and packed in boxes for shipment. Butter in this form usually brings at least one cent per pound more than tub butter. The prints should be wrapped in parchment paper, upon which the name of the creamery is neatly printed.

\section{How are butter tubs prepared for use?}

For about 24 hours before the tubs are to be filled with butter they should be soaked in a warm, saturated brine. This helps to destroy mold and closes the pores of the wood. The covers should be kept on the tubs to prevent warping. Just before the tubs are to be used they should be rinsed with warm water, then steamed, and then cooled with cold water. They are then ready to be lined with paper, and then filled with butter. The paper linings and circles should be soaked in a strong brine for a few hours before used. Many manufacturers are now using tubs coated with paraffin. This almost entirely prevents mold growth, and the tubs are ready for paper lining as soon as rinsed in cold water. 
How can mold be prevented from growing in butter?

I. By sufficiently soaking the tubs and linings in a strong salt solution before using.

2. By paraffining the tubs thoroughly on the inside.

3. By soaking the tubs and paper linings in solutions of formaldehyde.

What wood is the best for butter-tub construction?

For the larger tubs ash is used and for the smaller ones, spruce.

\section{How should butter be packed into tubs?}

The wooden butter ladles should first be cooled with cold water to prevent butter sticking to them. The butter should then be firmly packed in small amounts at a time and using plenty of muscle in the work. The circumference should receive more packing than the center, because when the butter is turned out of the tub for cutting, it is very necessary that the surface be free from all mechanical holes. Solid packing is of considerable aid in preventing the entrance of mold. The tubs should be filled to the top with butter. In filling, the butter should be heaped up and then leveled off by drawing a small wire or string across the surface. The extra butter can then be rolled off and the surface is left smooth and level.

The paper linings should be so fitted that they overlap about $I$ inch on the top surface. Then on top a cotton circle should be placed and over the circle a small amount of dampened salt is sprinkled. 
The covers are then applied, the weight of butter marked on the tub and it is ready for market.

What are the qualities of ideal butter?

It should have a clean, mild, creamy flavor, with a pronounced, mild, pleasant aroma. It should have close, solid, waxy body, free from buttermilk and undissolved salt. The color should be uniform and natural, and the finish should be neat, clean, and attractive.

How is butter judged?

A sample is drawn from the package by the use of a steel butter trier. As soon as drawn it is passed underneath the nose for the purpose of detecting the aroma. The color is then examined for defects and incidentally the brine is examined for free buttermilk.

The butter is then tasted and at the same time tested for undissolved salt by dissolving a small amount of butter between the tongue and roof of the mouth. The grain and body are also noticed and finally the finish and style of the package. It is usually better to criticise the finish first, before it is disfigured in any way.

What form is used for scoring butter?

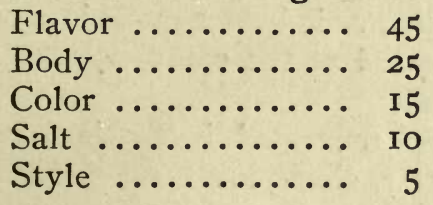

100 
What are some of the undesirable flavors commonly found in butter?

Rancid, unclean, cowy, fishy, weedy and tallowy, etc.

What are the common causes of undesirable flavors in butter?

1. Impure milk supply.

2. Cream exposed to bad odors.

3. Cream too old or too ripe before churning.

4. Undesirable bacteria found in all sorts of dirt and dirty places.

5. Impure water.

6. Foods that impart volatile flavors such as turnips, leeks, garlic, rape, etc.

7. Too much buttermilk retained in butter.

8. Holding butter at too warm temperature.

A bacterial flavor can usually be told from a food flavor, in that a food flavor generally passes off by pasteurizing and by the use of a commercial starter, while a bacterial flavor usually becomes worse with age.

What is the difference between creamery, process, renovated, factory, packing-stock, and grease butter?

Creamery butter is butter made in a creamery from cream separated at the creamery or gathered from farmers.

Process or renovated butter is butter made by melting butter, clarifying the fat therefrom and rechurning the same with fresh buttermilk, milk, cream, skim milk, or other such material. 
Factory butter is butter that is collected in rolls, lumps, crocks, and such forms, and reworked by a dealer or shipper.

Packing-stock butter is butter that is originally farm-made, reworked without additional moisture or salt.

Grease butter is made up of all butter that classes below third grade on the market. It must be free from adulteration.

\section{What is oleomargarine?}

The United States law defines oleomargarine as any substance containing animal or vegetable fats or oils, or any such products made in imitation or semblance of butter, or when so made calculated or intended to be used or sold as butter.

\section{What are the laws of the United States regarding oleomargarine?}

The laws on this substance are so changeable that it is impossible to give any set law for any state in such a book as this.

Some states prevent the manufacture of oleomargarine, others allow it to be manufactured if it is labeled and sold as oleomargarine, and a tax of so much per pound is paid, while still others do not require any tax. Some states, too, have laws preventing the use of coloring in products made in imitation of butter. In fact, the manufacturers of these products are so ingenious that they keep lawmakers busy in controlling them. The following extract from the laws of New York state give a good idea of the nature of an oleomargarine law26-38, page 18 : 
No person, by himself, his agents, or his employees, shall produce or manufacture out of or from any animal fats or animal or vegetable oils not produced from unadulterated milk or cream, from the same, the article known as oleomargarine or any article or product in imitation or semblance of natural butter produced from pure unadulterated milk or cream of the same; or mix, compound with or add to milk, cream or butter, any acids or other deleterious substance or any animal fats or animal or vegetable oils not produced from milk or cream, so as to produce any article or substance, or any human food in imitation or in semblance of natural butter. Nor sell, keep for sale, or offer for sale any article or substance or compound made, manufactured or produced in violation of the provision in this section, whether such article, substance or compound shall be made or produced in this state or elsewhere. Any person manufacturing, selling, offering, or exposing for sale any commodity or substance in imitation or semblance of butter, the product of the dairy, shall be guilty of a violation of [the agricultural law] this chapter, whether he sells such commodity or substance as butter, oleomargarine, or any other name or designation whatsoever, and irrespective of any representations he may make relative to such commodity or substance. Any dealer in any article or product, the manufacturing or sale of which is prohibited by this act, who shall keep, store or display such article or product with other merchandise or stock in his place of business, shall be deemed to have the same in his possession for sale.

\section{What is whey butter?}

Whey butter is butter made from the fat in cream separated from whey, which is a by-product in 
cheesemaking. Its quality depends largely upon the quality of the milk and whey, and the amount to be made depends upon the amount of fat lost in the whey in the process of cheesemaking. The amount varies between 2 pounds to 5 pounds in every I,000 pounds whey.

What are the common sources of loss in buttermaking?

I. Improper care of the milk.

2. Carelessness in sampling milk or cream.

3. Inaccuracy in reading fat in test bottles.

4. Carelessness or inability in running separators.

5. Errors in cream ripening.

6. Spilling milk or cream while handling it.

7. Inaccurate scales.

8. Carelessness or inability in churning.

9. Losses in buttermilk.

Io. Moisture content of butter may be too low.

II. Moisture may not be properly incorporated, allowing great shrinkage in weight.

12. Printing machines may not be accurate, giving overweight.

How is butter tested for its fat content?

I. By the ether method.

Evaporate a known weight, 2 to 3 grams, to dryness in a flat-bottom dish. Then wash the total contents of the dish upon a weighed filter paper, using about 50 c. c. of ether or naphtha. Then wash free from fat the residue on the filter, with ether or naphtha. The filter is then dried at $100^{\circ}$ C. to constant weight and weighed. The percent- 
age of fat is determined by the difference between weight of butter and weight of fat.

2. By Babcock test.

Weigh 4 grams of butter into a cream bottle, adding enough water to make 18 grams in the bottle. Add I 8 grams of sulphuric acid, and after thorough mixing, whirl in the centrifuge for five minutes. Add hot water at $200^{\circ} \mathrm{F}$. to raise the fat into the graduated part of the neck. Whirl again for two minutes, then multiply the reading on the bottle by $4 \cdot 5$.

How is the moisture content of butter determined?

I. By chemical analysis.

2. By practical moisture tests.

What are the names of the more commonly used moisture tests?

I. Cornell test.

2. Mitchell-Walker.

3. Irish.

4. Gray's.

5. Farrington.

How should a representative sample of butter be secured and prepared for making a moisture, salt, or fat test?

From the mass of butter to be tested take several samples from various parts. These samples, when added together, should make about 6 ounces. These are placed in a wide-mouth sample bottle or fruit jar and placed in hot water until the butter melts to the consistency of thin cream. While melting, the butter should be thoroughly stirred with a table knife or similar instrument. The bottle 
should then be well shaken to insure a uniform mixing of the sample. The bottle is then placed in cold water to solidify, but while cooling the butter should be stirred continuously. As soon as the butter has become fairly solid or plastic, the sample for testing can be secured. If in melting the butter becomes oily, great care must be used to reincorporate the water evenly during the cooling.

Describe and give directions for testing butter with the Cornell moisture test.

This is a simple, accurate, and durable test recently prepared by Mr. H. E. Ross of the dairy department of New York state college of agriculture.

The test resembles the Irish test, but has several important improvements.

A ro-gram sample of butter is secured in the usual way, and is placed in a special cast aluminum cup. The cup is then held over a flame with special forceps or placed on any heated surface.

The important features of the test are the use of the special cup and the use of a thin sheet of asbestos between the flame or heated surface and the cup. The asbestos prevents all sputtering of the heating butter and eliminates to a great extent the danger of charring.

The sample is heated till all moisture is driven off. This usually takes about 25 minutes, and is indicated by the casein losing its snow-white color and becoming brown. The sample is then cooled and reweighed with a special scale upon which the percentage moisture can be read directly and accurately. 
Describe and give directions for using the Irish moisture test.

A representative Io-gram sample of butter is obtained and placed in a small metal cup, then held over an alcohol flame with a pair of special forceps until all moisture has evaporated from it. While the butter is heating it foams considerably. As soon as the foaming has ceased, and before the fat begins to char, a small mirror is held over the cup to show if any moisture still remains. When the sample is thus freed from moisture it is cooled to room temperature and reweighed upon a special scale by which the difference between the weights of the butter before and after'heating is indicated in the form of moisture percentage by the use of small percentage weights.

Describe and give directions for using Gray's moisture test.

This test consists of a scale, a glass flask, a graduated glass tube, a condenser, an amyl reagent, and an alcohol lamp.

A representative ro-gram sample of butter is placed in the glass flask. To this 6 c. c. of amyl reagent is added and the different parts of the test then connected for use. The butter and amyl mixture is heated over a flame and the moisture is driven off into a graduated tube in the form of steam, where it condenses upon coming in contact with the condenser, which contains cold water. The moisture collects in the graduated tube and can be read in the form of percentage. The heating is stopped as soon as the mixture in the flask becomes brown and the crackling noise ceases. 
This usually requires about six minutes. Should too much heat be applied at once, the steam may go up above the 15 per cent mark. This should be prevented by withdrawing the heat for a short time. Great care must be exercised in collecting all the moisture in the graduated part if reliable readings or results are to be secured.

Describe and give directions for using the MitchellWalker moisture test.

The apparatus in this test consists of a metal evaporating cup, condenser, graduated glass receiver, scale for weighing sample, spirit lamp, amyl acetate reagent, and a stand to support the apparatus.

A representative Io-gram sample of butter is placed in the metal cup. To this is added ro c. c. of the amyl acetate reagent. The apparatus is then connected and the condenser filled with cold water. The alcohol flame is then applied under the evaporating cup. In about a minute the water and reagent will begin to pass over and pass from the condenser tube into the receiver. After all the water has been evaporated from the cup, the reagent will cease or almost cease dropping for a moment and then begin again as soon as it has reached its own boiling point, which is higher than that of the water. Continue to apply the flame until practically all the reagent is driven off and it ceases to drop freely from the condenser-tube. By this means all the water is washed out of the condenser tube and the major portion of the reagent is recovered. The flame is now extinguished. The mouth of the receiver is corked, and, taken by the top, is 
shaken a few times to detach any drops of water that may adhere to the sides.

The percentage moisture can now be read in the graduated receiver. The water is then withdrawn from the receiver and then the reagent, which is collected in a bottle and preserved for use in later tests.

Describe and give directions for using Farrington moisture test.

In Farrington's test Io grams of a representative sample of butter is placed in a small dish. The dish is then placed in a special Farrington oven heated from $240^{\circ} \mathrm{F}$. to $270^{\circ} \mathrm{F}$. under steam pressure. Here the butter is left until all moisture has been evaporated, as indicated by the browning of the casein. This usually takes about 25 minutes. After the moisture has been evaporated the dish and its contents is reweighed and the difference from the original weight determined. The percentage moisture can thus be easily determined. Example:

If original weight= Io grams, and weight after evaporation $=8 \mathrm{t} / 2$ grams, then evaporation of water must $=\mathrm{I} / 2$ grams.

If evaporation from to grams butter $=\mathrm{I} / 2 \mathrm{grams}$, then evaporation from Ioo grams butter would be

$$
\frac{11 \times 100}{10}=15 \text { grams. }
$$

$\therefore$ percentage water in butter $=\mathrm{I} 5$ per cent.

Occasionally a balance is used upon which, by using a reverse beam, the percentage moisture can be read direct.

What rules govern the sale of butter in New York? At the first regular meeting of the executive com- 
mittee in each year the president shall appointwith the approval of the executive committee-a butter committee to consist of seven members of the exchange, one of whom shall be a member of the executive committee, to hold office until their successors are duly appointed. It shall be the duty of the butter committee to formulate such rules and regulations as may be necessary for the government of transactions between members of the exchange, and to revise the same as circumstances may require. Such rules and revisions shall be subject to the approval of the executive committee.

Under direction of the superintendent of the exchange, who shall be instructed by the butter committee, there shall be a call, at such hour' as shall be prescribed, on each business day of the year, for the purchase and sale of butter.

All transactions in butter between members of the exchange shall be governed by the following rules:

\section{CLASSIFICATIONS}

I. Butter shall be classified as creamery, process, factory, packing stock, and grease butter.

\section{Definitions}

2. Creamery.-Butter offered under this classification shall have been made in a creamery from cream separated at the creamery or gathered from farmers.

3. Process.-Butter offered under this classification shall be such as is made by melting butter, 
clarifying the fat therefrom and rechurning the same with fresh milk, cream or skim milk, or other similar process.

4. FACTORY.-Butter offered under this classification shall be such as is collected in rolls, lumps, or in whole packages and reworked by the dealer or shipper.

5. Packing Stock.-Butter offered under this classification shall be original farm-made butter in rolls; lumps, or otherwise, without additional moisture or salt.

6. Grease Butter shall comprise all classes of butter grading below thirds, or of packing stock grading below No. 3 as hereinafter specified, free from adulteration.

\section{GRADES}

7. Creamery, process and factory shall be graded as specials, extras, firsts, seconds, and thirds; and packing stock shall be graded as No. I, No. 2 and No. 3 .

\section{Definition of Grades}

8. Grades of butter must conform to the following requirements:

\section{Specials}

9. Shall comprise the highest grades of butter obtainable in the season when offered, under the various classifications. Ninety per cent shall con- 
form to the following standard; the balance shall not grade below Extras.

Flavor.-Must be fine, sweet, clean and fresh, if of current make, and fine, sweet, and clean, if held.

Body.-Must be firm and uniform.

Color.-A light straw shade, even and uniform. Salt.-Medium salted.

PaCkage.-Sound, good, uniform, and clean.

\section{Extras}

Io. Shall be a grade just below specials and must be fine butter for the season when made and offered, under the various classifications. Ninety per cent shall conform to the following standard; the balance shall not grade below Firsts.

Flavor.-Must be sweet, clean, and fresh if of current make, and sweet and clean if held.

BoDy.-Must be good and uniform.

Color.-A light straw shade, even and uniform. SAlt.-Medium salted.

PACKage.-Sound, good, uniform, and clean.

\section{Firsts}

II. Shall be a grade just below Extras and must be good butter for the season when made and offered, under the various classifications. Ninety per cent shall conform to the following standard; the balance shall not grade below Seconds.

Flavor.-Must be good, sweet, and fresh, if of current make, and good and sweet if held.

BoDy.-Must be firm and fairly uniform. 
CoLon.-Reasonably uniform, neither very high nor very light.

Salt.-May be reasonably high, light, or medium. PACKAGE.-Sound, good, uniform, and clean.

\section{Seconds}

I2. Shall be a grade just below Firsts.

FLAVor.-Must be reasonably good.

BoDY.-If creamery, must be solid boring. If factory or process, must be 90 per cent solid boring. CoLoR.-Fairly uniform, but may be mottled.

SAlt.-May be high, medium, or light.

Package.-Good and uniform.

\section{Thirds}

I3. Shall be a grade below Seconds and may consist of promiscuous lots.

FLAVOR.-May be off-flavored and strong on tops and sides.

Bony.-Not required to draw a full trier.

Color.- May be irregular or mottled.

SAlt.-High, light, or irregular.

Package.-Any kind of package mentioned at time of sale.

\section{No. I Packing Stock}

14. Shall be sweet and sound, packed in large, new, or good uniform second-hand barrels, having a wooden head in each end, or in new tubs, either to be parchment paper lined. Barrels and tubs to be packed full. 


\section{No. 2 Packing Stock}

15. Shall be reasonably sweet and sound, and may be packed in promiscuous or different kinds of barrels, tubs, or tierces, without being parchment paper lined, and may be packed in either twoheaded or cloth-covered barrels.

\section{No. 3 Packing Stock}

I6. Shall be a grade below No. 2, and may be off-flavored, or strong; may be packed in any kind or kinds of packages.

I7. Charges for inspection of packing stock shall be the same as the rules call for on other grades.

I8. MoLD.-There shall be no grade for butter that shows mold.

\section{KNOWN MARKS}

I9. Known marks shall comprise such butter as is known to the trade under some particular mark or designation and must grade as ExTRAS, or better, if creamery or process, and as FIRSTS, or better, if factory in the season when offered, unless otherwise specified. Known marks to be offered under the call must previously have been registered in a book kept by the superintendent for that purpose. If process, the factory district number and state must be registered.

\section{SALES UNDER THE CALL}

20. Parties wishing to offer butter not described 
in the foregoing classifications and grades, must specify its character.

2I. All butter offered under the call shall be fresh made, current receipts, and shall be in regular 6o-pound ash tubs, unless otherwise specified.

22. No offer to buy or sell less than 25 tubs spot, nor less than 50 tubs for future delivery, nor bids or offers of a less fraction than $1 / 8$ cent per pound shall be entertained.

23. Bids and offerings of not less than 50 tubs for future delivery may be made for a period of 30 days. The call for futures shall take place immediately after the call for spot delivery. On all sales for future delivery, a compulsory margin shall be deposited by each party to the contract as specified in Rule 2 of the executive committee.

24. The first offer to buy or sell at a price, shall be accepted before subsequent offers at the same figure are considered.

25. Offers may be withdrawn at any time before acceptance.

26. Offers to sell at a lower, or buy at a higher price shall vacate all previous bids and offerings.

27. A transaction shall vacate all previous biđs and offerings.

28. All differences as to offers, acceptances, withdrawals, or irregular bids, shall be decided on the spot by the officer conducting the call, subject to an appeal to the members present. If an appeal is made, it shall be put promptly, and a majority of the members present and voting shall settle the difference finally. 
29. The superintendent shall have recorded daily, in a book kept for the purpose, all sales under the call, and such other sales on the floor as may be requested by the parties thereto, and shall furnish certificates of sales to both seller and buyer.

3o. Spot sales shall be for spot cash, and butter sold for future delivery shall be paid for when delivered, unless otherwise agreed.

3I. Unless otherwise specified all deliveries shall be from the store of the seller, or transportation terminals, providing it be in Manhattan borough below Canal street; otherwise, the goods must be placed within said limits.

32. All disputes must be settled while the goods are in the seller's possession.

32A. When spot sales are made, butter must be ready for immediate delivery.

33. All goods tendered, inspector's certificate attached, shall be accompanied by such certificate, and be accepted by the buyer unconditionally; provided, all tubs are branded according to Rule 6і.

34. If butter tendered which has not been sold certificate attached, does not appear to the buyer to be of the class and grade sold, the seller shall be notified not later than I P. M. He may then have it inspected, and if it proves not to fulfill the requirements of the sale, he may make a second delivery not later than 3 P. M.

35. If a second tender is made and appears not of the class and grade sold, the buyer must establish the quality by an official inspection for which he shall make application to the superintendent not later than 4 P. M. of the day of the sale. 
When an inspection is made, and shows the butter to be of the class and grade sold, the buyer shall accept the same, and pay for the inspection.

36. In sales for "future delivery" the delivery requirements as to time, inspection, etc., shall be the same as on spot sales on the date of delivery, but the rules governing classification for grades in force at time of such sales shall govern the quality of such deliveries.

37. In sales "seller's option" the seller shall notify the buyer of his intention to make delivery not later than 9 A. M. on day of delivery. If "buyer's option," the buyer shall notify the seller of his intention to call for delivery at least twentyfour hours before ro A. M. of the day delivery is demanded.

38. On sales of creamery of 25 tubs, delivery may be of not more than two marks; on 26 to 50 tubs, three marks; on $5 \mathrm{I}$ to IoO tubs, marks containing not less than 25 tubs each; on larger lots marks containing not less than 50 tubs each.

39. On sales of factory - or process butter, delivery must be of one mark, unless otherwise specified.

40. A carload shall consist of 300 tubs of one mark, unless otherwise specified.

4I. In case of failure to deliver a carload, settlement shall be made on the basis of 300 tubs.

42. An application to the superintendent for an inspection of goods in controversy, if made within the time allowed for inspection, shall be deemed a compliance with these rules in this respect. 


\section{PENALTIES}

43. When an inspection of butter sold for spot delivery shows the goods not to be of the class and grade sold, the seller shall pay a penalty equal to 5 per cent of the amount of the contract, and the fee for inspection. If the official quotation for the day exceeds the contract price, the seller shall also pay to the buyer in the same way the difference between the contract price and the average official quotation.

44. If butter purchased for future delivery be not delivered as per contract, the buyer shall promptly notify the superintendent in writing. At the next regular meeting of the exchange, an announcement of the same shall be made by the superintendent, who shall buy in the goods for account of the seller, provided it can be done under the call at current rates. If, however, the price demanded seems to him unreasonable, he shall not make the purchase, but shall refer the matter to the butter committee, who shall determine the difference between the contract price and the actual market value on the date on which delivery should have been made, and this amount, together with a penalty equal to 5 per cent of the amount of the contract, shall be paid by the seller.

45. If butter, sold for future delivery, be not received when properly tendered, the seller shall promptly notify the superintendent in writing. At the next regular meeting of the exchange, an announcement of the same shall be made by the superintendent, who shall sell out the goods, under the call, for account of the buyer, and if the price 
obtained be less than the contract price, the difference, together with a penalty equal to 5 per cent of the amount of the contract, shall be paid by the buyer.

46. Penalties and differences shall be paid to the superintendent of the exchange, and by him paid to those entitled thereto.

47. Any member holding a contract against another, corresponding in respect to class, grade and quantity of goods, and date of delivery, with one held by the other against him, may offset it against the latter by giving notice to the other party, when both contracts shall be surrendered to the superintendent of the exchange and canceled.

48. All notices shall be in writing, and shall be considered as properly served when left at the place of business of the party for whom they are intended.

\section{CERTIFICATE OF SALE}

49. Certificates of sale must be accepted on contracts for future delivery.

50. The party transferring a certificate of sale, shall immediately notify the original seller of the transfer, and to whom made. He shall also have it recorded on the books of the exchange, and shall thereupon be relieved of all responsibility attaching to the same.

51. In case the party to a contract for future delivery, for the fulfillment of which margin has been deposited with the superintendent, shall die, make an assignment, be absent from the city, or otherwise be disabled, or refuse to perform any act necessary. for the proper adjustment or payment of 
such margin, the matter shall be referred to the finance committee, as provided in section 33, paragraph 6 , of the by-laws.

\section{CONTRACTS}

52. The following shall be the form of contract. for all sales of butter for future delivery.

\section{CONTRACT FOR FUTURE DELIVERY}

No......

This is to certify that the following sale and purchase has been made by the respective signers hereto, under and subject to the rules of the New York Mercantile Exchange, this................

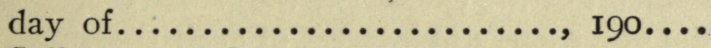

Seller

Address

Purchaser

Address

Quantity

Grade

Class

Price

Delivery

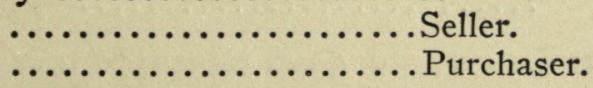

Original margin deposited with me this day by each party hereto.................... dollars. .................... Superintendent.

New York, ..............., I90.... 
Upon the reverse side of each contract shall be printed the rules governing such transactions. A proper book shall be kept by the superintendent of the exchange, entitled "Butter Contracts," in which shall be recorded all contracts as per foregoing form, duplicates of which shall be furnished to both sellers and purchasers, who shall personally sign the same at the time of depositing original margins. All contracts shall be signed, and original margins deposited not later than 2 o'clock on the day following the sale.

53. When further margins are called for, same shall be paid to, and receipted for, by indorsement upon the contract by the superintendent of the exchange.

54. All transfers of contracts for future delivery must be indorsed on the original contract, by the superintendent of the exchange, who shall promptly notify the other party in interest of such transfer.

55. The following form of transfer shall be used:

"For value received, the within described contract is assigned and transferred to...$\ldots \ldots \ldots \ldots$ who hereby agrees to assume the same, with all the conditions and obligations thereof.

Dated, New York, ................ I9o.... Seller.

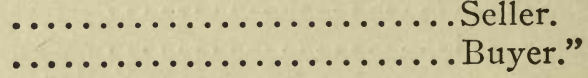

\section{INSPECTORS AND INSPECTIONS}

56. The butter committee shall recommend to the president, for his appointment, subject to the approval of the executive committee, such inspectors of butter as may be required. 
57. Vacancies occurring in the office of inspectors shall be filled in the manner in which the original appointment was made.

58. In case of absence, or inability of the inspectors, temporary inspectors may be appointed by the butter committee of the exchange.

59. Inspectors, before entering upon their duties, shall take and subscribe to the following oath:

I, ................ do solemnly swear that I will execute the duties of an "Inspector of Butter" for the New York Mercantile Exchange, with strict impartiality and according to the best of my ability, that I will, in making my inspections, follow carefully the rules adopted and the instructions given me by the butter committee. That I will fearlessly perform my duties, make each inspection according to the merits of the butter, and render my certificates accordingly. That I will not allow a second party to examine and comment while I am making an inspection.

That I will promptly report in writing to the butter committee the name of any firm, company or member that makes any suggestions, or requests relative to any inspection that I may make, as well as a full detailed report regarding the occurrence; further, that I will accept no gratuity of any kind or nature whatsoever other than the salary paid to me by the exchange.

Sworn and subscribed before me this. day of..............., I90....

Notary Public. 
6o. All applications for inspection must be made to the superintendent of the exchange between the hours of $8 \mathrm{~A}$. M. and 5 P. M., who will direct the same-For Members of the Exchange Only-as soon as practicable, in the order in which they are received, excepting that applications for the inspection of butter which has been sold under the call, and is in controversy, shall be given precedence over other applications.

6I. Inspectors shall brand on the top and side each package inspected, and, when requested, also on the side of each remaining package in the lot, or lots, covered by the inspection.

62. Inspectors shall, immediately after completing an inspection, make a certificate of the same in accordance with the specification for grading, contained in these rules, upon blanks furnished for this purpose, under the direction of the butter committee; which shall be countersigned by the superintendent, and promptly delivered to the party ordering the inspection.

63. A certificate of inspection shall be good for two days from date of same (including Sundays and holidays), provided the holder of the goods takes proper care of the same.

64. The inspectors shall have recorded in a book provided for the purpose, a detailed account of all inspections made by them, stating date and hour of inspection, name and address of parties from whom inspection is made, place where inspection is made, stencil number or other marks on goods, number of tubs in lots and number of tubs inspected. If lots contain more than one shipment, the number of tubs in each shipment shall be noted. 
65. There shall be drawn as samples for inspection by the inspectors:

5 tubs from lots less than 25 of one mark and invoice;

8 tubs from lots of 25 of one mark and invoice; I 5 tubs from lots of 50 of one mark and invoice; 20 tubs from lots of 100 of one mark and invoice; 35 tubs from lots of 200 of one mark and invoice; 50 tubs from lots of 300 of one mark and invoice; 60 tubs from lots of 500 of one mark and invoice; and a like proportion of lots ranging between these figures, and of larger lots

66. If butter runs irregular in quality, the inspector shall increase his sample to such an extent as he may deem necessary to secure a fair and just inspection.

67. A buyer or seller may have a larger percentage than the above inspected, upon making application previous to the inspection, and payment of ro cents per tub additional fees.

68. All complaints against the butter inspectors shall be referred to the butter committee.

69. Charges for inspection shall be as follows: In the borough of Manhattan, below Fourteenth street and outside of that district, the minimum charge shall be $\$ \mathrm{I} .5 \mathrm{O}$.

On lots not exceeding Io tubs, I invoice... \$ .50

Over Io and not over 25 tubs, I invoice... $\quad .75$

Over 25 and not over 50 tubs, I invoice.... I.OO

Over 50 and not over Ioo tubs, I invoice.... I.5O

Over IOO and not over 200 tubs, I invoice.... $\quad$ I.75

Over 200 and not over 300 tubs, I invoice... 2.00

Over 300 and not over 500 tubs, I invoice... 2.50 
7o. Inspections shall be paid for by the party ordering the same, except where otherwise provided.

7I. The butter committee shall recommend to the president for appointment, subject to the approval of the executive committee, a butter weigher, who may appoint assistants as he may require them.

72. The butter weigher shall receive his instructions from the butter committee.

73. The butter weigher and assistants, before entering upon their duties shall be sworn to perform said duties faithfully, correctly and in conformity with the customs of the butter trade, as defined by the butter committee.

74. The butter weigher shall make certificates in duplicate of all lots of butter weighed by him, or his assistants, and promptly deliver to the party ordering the weighing.

75. Applications for weighing butter shall be made to the superintendent, or butter weigher.

76. Charges for weighing shall be as follows:

On lots not over 25 tubs........... 3 c. per tub

Over 25 and not over 50 tubs....... $2^{\mathrm{T}} / 2 \mathrm{c}$. per tub

Over 50 and not over 100 tubs..... 2 c. per tub Testing 7 tubs or less.......... 75 c.

Over 7 tubs .................. Io c. per tub

77. All complaints against the butter weigher, or assistants, shall be made to the butter committee.

78. All former rules conflicting with the foregoing are hereby repealed.

Attention is Directed to the Following Executive Committee Rules, and Section 33, Paragraph 6 , of the By-laws.

RULE 2. On all sales, or purchases of any mer- 
chandise to arrive, or for future delivery, each party to the contract shall deposit an original margin with the superintendent of the exchange of Io per cent on the contract price at the time of purchase, or sale, and a further margin from time to time to the extent of any variation in the market value from the contract price; said margin to be deposited in such bank or trust company as may have been designated by the finance committee of the New York Mercantile Exchange. When margins are called before I2 M., they must be deposited before 3 P. M. of the same day. If called after I2 M., they must be deposited before I2 M. of the following day; in case of failure to deposit as above, the buyer or seller shall have the right to cover his contract at discretion, for account of the party failing to respond to the call for margin.

RULE 7. All merchandise purchased by sample shall be considered sold, unless the purchaser notify the seller within twenty-four hours after receipt of the same that it is rejected as not being up to sample. If a settlement cannot be agreed on, the case shall be referred to the trade committee having charge of the class of goods in question, who shall decide the matter, and in the event of a decision against either buyer or seller, the same penalties shall accrue as the Rules for sales under the $\mathrm{Cal}$ provide for the kind of goods dealt in. The party, against whom the decision is given, shall pay to each committeeman serving $\$ 2$ for each case.

\section{Section 33, Paragraph 6, of the By-laws}

When the parties to a contract, on which margin has been deposited through the instrumentality of 
the superintendent, as above set forth, cannot agree as to the distribution and payment of such margin, or in case one or both of the contracting parties die or make an assignment, or otherwise become incapacitated, or refuse to perform promptly any act necessary for the adjustment and payment of such margin, the finance committee is hereby authorized and directed to ascertain the person or persons to whom such margin should be paid, and instruct the superintendent to indorse the deposit certificate for payment, or exchange it for other checks, to correspond in amount with the committee's decision, drawn to the order of the person or persons entitled thereto, and deliver the same to said person or persons without unnecessary delay; and in case, for any cause whatever, the said deposit certificate is not immediately forthcoming, so that such indorsement and distribution may be made, the finance committee shall instruct the superintendent to procure from the said bank or trust company that issued it, a duplicate thereof, as provided for in the original, and indorse it as he would have indorsed the original if it had come into his possession.

What method of sewage disposal is advisable for creameries?

This depends on the location of the creamery and the character of the surrounding soil. One or more of the following methods can usually be successfully installed:

I. Removal by cartage. 2. Direct disposal into lakes and rivers if laws permit. 3. Cesspools. 4. Septic tanks and filter beds. 
Excessive skim milk and such material useful for feeding purposes should not be wasted in sewage, but should be carted away and fed to hogs.

When the laws of the state permit the direct disposal of creamery sewage into lakes and large rivers, it makes a most satisfactory system. In the case of small rivers and other small bodies of water, however, most states have laws preventing their use for such purpose. Then it becomes necessary to use one of the other systems. If the soil surrounding the creamery is of a sandy nature, it will have good filtering qualities so that a cesspool placed at a safe distance from the well should answer in most cases.

When the surrounding soil is of clay and with little elevation, it becomes necessary to construct a filter bed of sand and stone and to pass the sewage first through a septic tank. 



\section{N D E X}

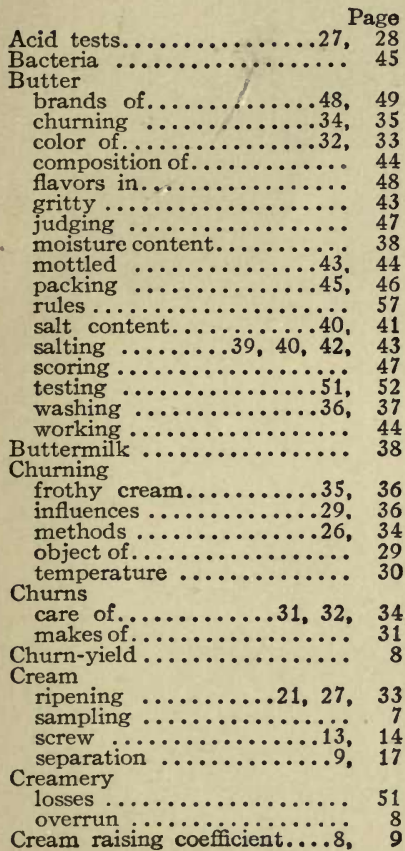

Fat

Page

composition ............ 2

globules ............... 2

melting points........... 3

non-volatile ............. 3

volatile $. . . \ldots \ldots \ldots \ldots \ldots . \quad 3$

Fermentation test........... 4

Ferments $\ldots \ldots \ldots \ldots \ldots \ldots, 4$

Milk

color .............. 4

composition ............., 2

ferments $. \ldots \ldots \ldots \ldots \ldots \ldots \ldots, 4$

heating..$\ldots \ldots \ldots \ldots \ldots \ldots 10$

sampling $\ldots \ldots \ldots \ldots \ldots \ldots \ldots$, 7

sugar $\ldots \ldots \ldots \ldots \ldots \ldots \ldots, 3$

tests.................. 6

Moisture tests.......... 54

Oleomargarine

composition ............ 49

laws $\ldots \ldots \ldots \ldots \ldots \ldots . . .49,50$

Overrun $\ldots \ldots \ldots \ldots \ldots \ldots \ldots . .8$

Pasteurization

advantages ............. 19

disadvantages ............ 19

effects ................ 4

methods $\ldots \ldots \ldots \ldots \ldots 18,19,20$

Salt

composition ........... 39

effects of............., 41

tests for.............41, 42

Separators

care of.............16, 18

speed of................. 15

varieties $\ldots \ldots \ldots \ldots \ldots \ldots \ldots . .10$

Separator slime............ 13

Spores ..................

Starters $\ldots \ldots \ldots \ldots \ldots \ldots \ldots \ldots \ldots \ldots, 25$

Sterilization .............. 19

Water purification.......... 38

Whey butter............50, 51 





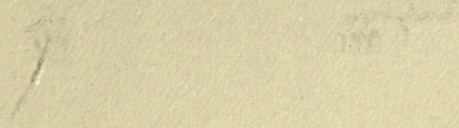




\section{RETURN TO the circulation desk of any}

University of California Library

$$
\text { or to the }
$$

NORTHERN REGIONAL LIBRARY FACILITY

Bldg. 400, Richmond Field Station

University of California

Richmond, CA 94804-4698

ALL BOOKS MAY BE RECALLED AFTER 7 DAYS

2 -month loans may be renewed by calling

(510) 642-6753

1 -year loans may be recharged by bringing books to NRLF

Renewals and recharges may be made 4 days prior to due date

DUE AS STAMPED BELOW

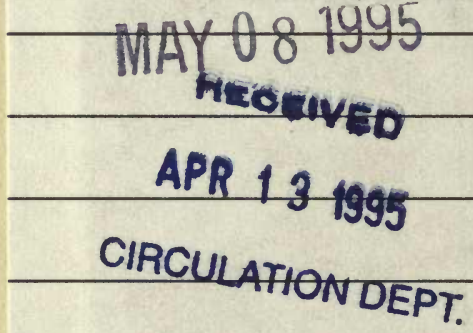





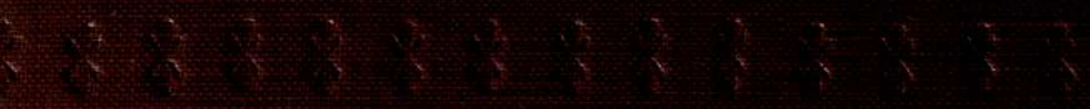

(1) 